\title{
Breaking the Syllabic-accentual Monotony
}

\section{Mihhail Lotman*}

\begin{abstract}
Ants Oras's innovation was not confined to the sphere of language, he also has an important role in the enrichment of Estonian metrics and systems of versification. His sources were mainly the forms of different European poetic cultures, which he introduced in his translations. In the paper, two meters are studied, which Oras tried to create in his translation of Goethe's Faust, in order to adequately convey the original's rhythm. These verse meters are German national form, Knittelvers, and adoneus derived from ancient and medieval verse. One common characteristic for these meters is the breaking of syllabic-accentual monotony.
\end{abstract}

Keywords: Ants Oras, Knittelvers, adoneus, Estonian verse, Faust, translation

1. The Estonian verse culture developed in the second half of the 19 th century under the influence of two traditions. The more important of the two is the adaptation of German syllabic-accentual verse with the means of the Estonian language. The second was the Estonian folklore tradition. These two foundations were not independent from each other, since Estonian folklore verse had entered Estonian literary poetry through the German prism. On the other hand, it was not as much influenced by the German high culture as it was by secondary authors and song books, both ecclesiastical and secular. The main verse meter was syllabic-accentual trochee which, since the epic "Kalevipoeg" (1862), had already been closely associated with popular poetry. From German poetry, rhyme and the alteration of clauses were transplanted. Thus, in the end of the 19th century the Estonian metrical and stanzaic repertoire seemed rather ascetic, if not to say meagre. The quatrains of trochaic tetrameter with the rhyme scheme $\mathrm{AbAb}$ (where capital letters mark feminine rhymes, lowercase latter masculine rhymes) prevailed nearly absolutely (the incidence of all other forms was less than 25\%, including the other stanzaic forms of trochaic tetrameter, compare Peep 1969: 433-434; Põldmäe 1978: 116). Such paucity of verse forms was in harmony with the realist poetic world, as well as with poetry oriented on singing.

\footnotetext{
* Author's address: Mihhail Lotman, Department of Semiotics, University of Tartu, Jakobi 2, 51014 Tartu, Estonia, e-mail: mihhail.lotman@gmail.com.
} 
Not only were meter and stanzas monotonous, but so was rhythm. This had also been proliferated by the German verse tradition, since the meter of folklore regisong (even if conditionally classified as trochaic tetrameter) is rich in rhythmic variations. German syllabic-accentual verse (both iambic and trochaic) is, in comparison with English, Russian and even Estonian verse, very monotonous, because in almost $100 \%$ of cases all strong positions bear stress. Few rhythmical modulations occur from the contrast between syllables with primary and secondary stress.

There are two reasons why the German iamb was that rigorous, particularly as compared to English iamb where numerous rhythmical licences are admitted. The first reason is historical. While the English iamb developed in evolutionary way, when the syllabic-accentual verse was derived from the Old-English accentual verse, to which syllabic constraints were added under the influence of Italian verse (in this context, first of all, Geoffrey Chaucer has to be mentioned); however, the German iamb was born like Athena from Zeus's head in its readymade form from the treatise by Martin Opitz (1624). The norms and rules of English iamb followed the actual practice, although Classicist authors tried to considerably limit its rhythmical freedom with their prescriptions. Nevertheless, the strictest English iamb is freer than the freest German iamb. The other reason is synchronic. English iamb eventually replaced the older meter, and, when in the 19th century the attempts were made to recreate the archaic verse, it was no longer associated with iamb. The situation was different in Germany, where, first, Knittelvers became syllabic in Hans Sachs's poetry, and, second, in parallel the accentual verse at least partly retained its position.

Opitz's newly reformed iamb superseded the syllabic verse typical of Hans Sachs, while the accentual Knittelvers continued to be used even though the iamb significantly restricted its practice ${ }^{1}$. Existing in parallel with Knittelvers, the iamb had to become clearly distinguishable from it, and, since from the standpoint of metrics we are dealing with almost identical forms, the differences were, primarily, in the degree of rhythmical freedom. This is demonstrated in these lines by Goethe:

(1) Habe nun, ach! Philosophie, Juristerei und Medizin, Und leider auch Theologie [...]

\footnotetext{
1 Andreas Heusler distinguishes between two types of Knittelvers: a strict syllabic form in Hans Sachs, were 8- and 9-syllabic verses (depending on the ending) alternate, and a free or accentual form, where the number of syllables is not fixed (Heusler 1929: 42-60, 327-354).
} 
From not only the English perspective, but also from a considerably stricter Russian verse culture, these are correct iambs in every way. In German iamb, however, such rhythmical moves, where the strong position is filled with the pre-stress syllable (compare Philosophie, Juristerei, Medizin, Theologie), which are not allowed, such rhythmical modulations indicate that we are dealing not with iamb, but with Knittelvers (Chisholm 1975: 20, 77, 129-130)2.

When we speak of the Estonian iamb, such rhythmical moves as in the citation above are not possible for purely linguistic reasons, since in Estonian, the word stress is fixed on the first syllable.

2. Modernism was slightly late in coming to Estonian culture, and entered poetry in the first decade of the 20th century. In verse culture it meant, first, the dramatic increase of different metrical and stanzaic forms, while at the same time the possibilities of quantitative verse were discovered and experimented with in various verse forms. Second, in the already established forms, new ways of expression and breaking the monotony were sought out (Lotman, Lotman 2013, 2014). The horizon was broadened, and in looking for new modes of expression the orientations shifted from the German tradition, first of all, to French and Russian poetic culture. Simultaneously, other Romance verse traditions played a certain part as well, in particular, in stanzaic structures. From that point on, attempts were made to convey the ancient verse with authentic models, not only through the prism of the German tradition (compare the 19th century accentual-syllabic hexameter by Jaan Bergmann).

Ants Oras, one of the leading figures of the Arbujad (Sorcerers), was one of the main ideologists of this reorientation and enrichment of Estonian verse, which first started with such literary groups as Noor-Eesti (Young Estonia) and Arbujad. All the more interesting is the fact that, in order to break the syllabic-accentual monotony, Oras turned also to German sources, first of all, in his translation of Faust.

Goethe's Faust is a polymetrical work with a sophisticated composition. The majority of the verses consist of syllabic-accentual lines, but there are some meters which break the syllabic-accentual monotony. One of these is Knittelvers, the meter of Germanic origin, the other adoneus which was used already in the Antiquity (it is primarily known as the last part of the Sapphic

2 In the statistics of German iambic tetrameter provided by Evgeny Kazartzev there occur such lines as $x x x X x X x X(x)$, yet in none of his examples does the pre-stress syllable occur in the second position, compare Um von Eugén Bestánd zu lérnen (Kazartzev 2011: 259), where the secondary stress occurs on the second syllable. 
stanza $\left.^{3}\right)$. Here Goethe had probably oriented already toward the medieval Latin tradition, where adonic verses were used also in stichic hymns. Even more exciting is the fact that both meters are often not distinguished as compositional units, but are smoothly integrated into syllabic-accentual context.

Let us start with the Knittelvers. Knittelvers in Faust proceeds from the same metrical structure as the iambic tetrameter. This structure (MS) can be presented in the following way:

(MS1) ABABABAB (A),

where $A$ and $B$ are abstract elements, about which nothing positive can be claimed. The only thing that characterises them is: $A \neq B$.

German iamb has very simple and strict correspondence rules (CR):

$\left(\mathrm{CR}_{\mathrm{i}} 1\right)$ Each position A or B corresponds to one, and only one, syllable.

(CR 2 ) Each position A corresponds to an unstressed syllable of a polysyllabic word or a monosyllabic clitic.

(CR 3 ) Each position B corresponds to a syllable carrying the primary or secondary stress (Nebenton) or to an unstressed syllable in post-stress position.

Consider the following verses:

(2) Die Sonne tönt, nach alter Weise,

In Brudersphären Wettgesang,

Und ihre vorgeschriebne Reise

Vollendet sie mit Donnergang.

Ihr Anblick gibt den Engeln Stärke,

Wenn keiner sie ergründen mag;

die unbegreiflich hohen Werke

Sind herrlich wie am ersten Tag.

(Prolog im Himmel)

Such verse may seem a little monotonous, but is solemn and is associated with Opitz's and Günther's odic tradition. Knittelvers with its loose rhythm harmonising with Faust's fickle mood is in contrast with it:

\footnotetext{
According to the contemporary approach, Sapphic stanza is often interpreted as a threelined structure (see, for example, Webster 1970: 76), while adonic verse is the last unit of the third verse. In Goethe's time it was interpreted as a four-lined stanza, while the first three lines were Sapphic hendecasyllables and the fourth adoneus.
} 
(3) Habe nun, ach! Philosophie,

Juristerei und Medizin,

Und leider auch Theologie

Durchaus studiert, mit heißem Bemühn.

Da steh ich nun, ich armer Tor!

Und bin so klug als wie zuvor;

Heiße Magister, heiße Doktor gar

Und ziehe schon an die zehen Jahr

Herauf, herab und quer und krumm

Meine Schüler an der Nase herum -

Und sehe, daß wir nichts wissen können!

Das will mir schier das Herz verbrennen.

(Erster Teil)

(Underlined are the places where the rules of iamb are violated.)

Differently from the German iamb, in Faust's Knittelvers the number of syllables, varying in the interval 8-10, as well as the placement of stresses and even the number of accentual positions are not strictly fixed here (in this fragment, the verse Heiße Magister, heiße Doktor gar has five beats). Let us focus on four-beat lines, which should be considered the main variant of Knittelvers.

The metrical scheme of this passage is the same MS1, but there are major differences in the correspondence rules:

$\left(\mathrm{CR}_{\mathrm{k}} 1\right)$ Each position $\mathrm{B}$ corresponds to one and only one syllable.

$\left(\mathrm{CR}_{\mathrm{k}} 2\right)$ Each position A corresponds to one or two syllables.

$\left(\mathrm{CR}_{\mathrm{k}} 3\right)$ Each position A corresponds to an unstressed syllable as well as the stressed syllable of a mono- or even disyllabic word.

$\left(\mathrm{CR}_{\mathrm{k}} 4\right)$ Each position B corresponds to an optional syllable.

Here are some examples of violations of iambic rules in Goethe's Knittelvers:

Habe nun, ach! Philosophie

$\mathrm{Xx} \mathrm{xX} \mathrm{xxxX}$

Both the first two syllables ( $\underline{\text { habe }}$ ) and the sixth syllable (Philosophie) violate the accentual principle of iamb: the first syllable carries the stress of the disyllabic word, the sixth position is filled with the pre-stress syllable of the polysyllabic word.

Durchaus studiert, mit heißem Bemühn.

$\mathrm{xX} \mathrm{xX} \mathrm{xXx} \mathrm{xX}$

In this verse the syllabic principle of iamb is violated: the fourth A-position is filled with two syllables (heißem Bemühn). 
The rhythm of Knittelvers is more ambiguous, as compared to iamb, and some lines are ambivalent in principle:

Meine Schüler an der $\underline{\text { Nase herum }}$

$\mathrm{Xx}$ Xx xxXx xX

In three of the four disyllabic words (meine, Schüler and Nase) the stressed syllable occurs on position A, with the main problem being the trisyllabic interval between stresses. Since the rules of Knittelvers do not allow it, it is possible to treat this verse as nonmetrical. However, in freer type of Knittelvers, the rules are not deterministic, but statistical. A more probable explanation is another interpretation, albeit complicated, according to which, this line is still metrical: position $\mathrm{A}_{3}$ corresponds to two (and not three) syllables:

Meine Schüler an der Nase herum

\section{$\mathrm{Xx} X \mathrm{Xx} x \mathrm{Xx} \mathrm{xX}$}

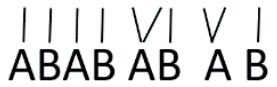

3. Knittelvers has to be distinguished not only from iamb, but also from the four-stressed meter which, in Russian verse theory, is called dolnik (Tarlinskaja 1992). If we proceed only from the surface structure, we are dealing with the same model, where anacrusis can vary from 0-2 syllables, that is, the beginning of verse can be dactylic, amphibrachic or even anapaestic, 1-2 syllables can be put between the strong positions, and the end of line can be masculine, feminine or even dactylic:

$$
(\mathrm{x})(\mathrm{x}) \mathrm{Xx}(\mathrm{x}) \mathrm{Xx}(\mathrm{x}) \mathrm{Xx}(\mathrm{x}) \mathrm{X}(\mathrm{x})(\mathrm{x})
$$

The difference is that Knittelvers is a binary meter (iamb) in its deep structure, while dolnik is based on ternary meters. Some versification scholars, who extrapolate only from the surface structure, disregard this difference, and thus, Goethe's Erlkönig is treated as Knittelvers (compare Altmann, Altmann 2005). Such interpretation is, however, problematic, and it would be more correct here to speak of accentual verse (Bailey 1969) or, more accurately, dolnik (Tarlinskaja 1993: 13). It is a rather delicate, but fundamental problem, which cannot be resolved, for example, statistically. In dolnik, the incidence of monosyllabic intervals can be even higher than that of disyllabic intervals. What is decisive is not the quantity, but the deep structure, on the background of which we perceive this verse, as a verse meter is a Gestalt in its own way (Lotman 2011). 
(4) Wer reitet so spät durch Nacht und Wind?

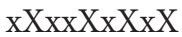

Es ist der Vater mit seinem Kind;

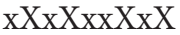

Er hat den Knaben wohl in dem Arm,

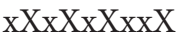

Er fasst ihn sicher, er hält ihn warm.

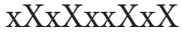

Theoretically, this poem can also be read against the background of iamb, thus the interpretation of the meter is ambivalent. An amphibrachic interpretation is, however, preferable because, among other things, differently from Knittelvers, in this interpretation the unstressed syllables do not occur in stressed positions. Lines with a rhythm such as 'Juristerei und Medizin' are not possible in "Erlkönig".

Both in Knittelvers and dolnik, purely iambic (or even trochaic) verses as well as verses in ternary meters can occur. Consider, for example, a purely iambic initial line in Heine's poem, "Die schlesischen Weber":

(5) Im düstern Auge keine Thräne,

Sie sitzen am Webstuhl und fletschen die Zähne:

Deutschland, wir weben Dein Leichentuch,

Wir weben hinein den dreifachen Fluch -

\author{
$\mathrm{xXxXxXxXx}$

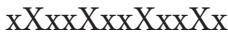

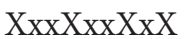

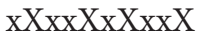

Just like in the case of Erlkönig, the meter of this text is dolnik and not Knittelvers ${ }^{4}$. It is important to note that this difference was clearly perceived by Goethe, as well. Although he used to write in both meters, in Faust only Knittelvers occurs. The contrast between Knittelvers and the "pure" iamb is much weaker than the contrast between iamb and dolnik, and when Goethe uses Knittelvers, he mitigates the rhythmic contrast. Furthermore, more important is the difference between the semantic connotations of the iamb and the Knittelvers of Faust (Arndt 1968: 37-38).

4. Goethe's Faust is a popular work in Estonia. Several poets have translated its various fragments, but there are three full translations: the first by Anton Jürgenstein (1920), the second by Ants Oras (1955), and the third by August Sang (1972).

\footnotetext{
4 "Generally speaking, the meter of the first poem [Goethe's Hans Sachens Poetische Sendung] is basically iambic, while that of the second [Erlkönig] is more like the dactylic meter which Goethe occasionally used in ballads" (Chisholm 1975: 22). In German versification, the term 'dactyl' sometimes designates all ternary meters.
} 
All three translators make an attempt to convey the contrast between the syllabic-accentual verse and Knittelvers, yet, while each of the models of Knittelvers are different from the aspect of rhythmics, Oras's version is the freest.

The Estonian tradition has no equivalent to Knittelvers. However, as a peculiar case, the so-called vemmalvärss could be mentioned as an exception. Vemmalvärss means the same as Knüttelvers (vemmal is 'club, cudgel', värss is 'verse'). Just like Knittelvers, it developed when the versification of the folklore tradition became syllabic-accentual, in the course of which quantity substantially lost its significance, while the importance of stress grew. In a parallel process, similarly to Germanic verse, alliteration was replaced with end rhyme, and just like in Knittelvers, the rhyming couplets prevailed. An important difference is that the deep structure of Knittelvers is iambic, while that of vemmalvärss is trochaic. Furthermore, it is not clear how the term 'vemmalvärss' evolved and how it is related to Knittelvers.

Hence, the Estonian translators could not use Knittelvers in its ready-made form, but had to construct it. Every translator solved this problem in his own way. The first translator, Anton Jürgenstein, created a minimum contrast between iamb and Knittelvers, compare the same verses from the Prologue in Heaven (6) and Faust's monologue (7):

(6) Waat, päikest kõlab endist moodu Suur wennas-ilma wõidulaul, Ja seatud käigul ühte soodu Ta lendab piksemaru aul.
(7) Küll mõttetarkust olen ma Ja õigust, rohuteadust uurind, Ja kahjuks teoloogia Ja kõik, kõik kangest läbi puurin'd.

The main difference between iamb and Knittelvers in Jürgenstein's translation is not metrical nor even rhythmical, but prosodical: Knittelvers is prosodically more free. Compare the inconsistent treatment of diphthongs - for Jürgenstein, these are at places disyllabic, for instance:

Ja wean kümme aastat ma

$\mathrm{Xx}$

and at places, diphthongs (that is, in one syllable):

Oh saaksin mäele kõrgele

$\mathrm{X}$

Siin purke, pudeleid näeb silm

$\mathrm{X}$

Secondly, there are the syncopes: waatsid pro waatasid, kangest pro kangesti, puurin'd pro puurinud. He allows such licences in iambs, too, but in Knittelvers the incidence of these is much higher. 
(8) Siis, kurblik sõber, waatsid sa

$\mathrm{x} \mathrm{Xx} \mathrm{Xx} \mathrm{Xx} \mathrm{X}$

Ja kõik, kõik kangest läbi puurin'd.

$\mathrm{xX} \mathrm{x} \mathrm{Xx} \mathrm{Xx} \mathrm{X}$

Though there are also Knittelvers-like rhythmic moves which contain redundant syllables from the aspect of iamb:

(9) Ja näen, et me midagi ei tea

$\mathrm{xX} \mathrm{xx} \mathrm{XxX} \mathrm{xX}$

Mustkunst, su wõtan nüüd käsile

$\mathrm{xX} \mathrm{xXx} \times \mathrm{XxX}$

Kuid rõõmust olen ka üsna lahti

$\mathrm{xXx} \mathrm{Xx}$ x Xx Xx

Ei mingist täitsa aru saada mahti

$\mathrm{xXx} \mathrm{Xx} \mathrm{Xxxx} \mathrm{Xx}$

Ei usu, et tarkust wõin edasi kanda

$\mathrm{xXx} \times \mathrm{Xx}$ x $\mathrm{Xxx} \mathrm{Xx}$

Ehk teistele paremaid mõtteid anda

$\mathrm{xXxx} \mathrm{Xxx} \mathrm{Xx} \mathrm{Xx}$

Oras solves this issue in a different way. For him, iamb and Knittelvers are much more clearly distinguished, and in the latter the accentual principle is strengthened. As a result, the heterometrical stress meter evolves, in which verses with three or four stresses prevail. For example, in the beginning of Faust's monologue, some lines can be interpreted as different syllabic-accentual meters, while in the general context the interpretation as stress meter is preferable.

(10) Olen nüüd, ah, filosoofiat,

$(\mathrm{T} 4=\mathrm{Do} 2)$

juurat ja meditsiinigi uurind,

ja kahjuks ka teoloogiat

$(\mathrm{Ia} 4=\mathrm{Do} 2)$

kibedal õhinal õppind ja puurind -

(D4 = Do4)

ning siin ma, rumal, vilets vend,

$(\mathrm{Ia} 4=\mathrm{Do} 4)$

näen sama targalt kui ennegi end...

(Do4)

(D4 - dactylic tetrameter; Do2, Do4 - two- and four-stressed dolnik;

Ia4 - iambic tetrameter, T4 - trochaic tetrameter)

Already the German Knittelvers is much more ambivalent, as compared to strict syllabic-accentual verses (Chisholm 1975: 80-85). In Oras's verse the iambic support is weakened and the ambivalence is even higher. For example, the first line, Olen nü̈̈d, ah, filosoofiat, can be interpreted as trochaic

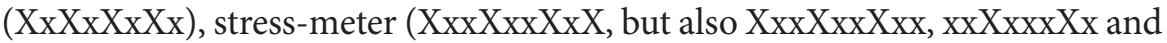
so on), but under no circumstances as iambic. Although the fifth line is a pure iamb, in this passage the iambic impulse is poorly perceived.

The most interesting solution is offered by Oras's disciple August Sang, the only translator who tried to gain a footing from the tradition of vemmalvärss. 
Since vemmalvärss is not based on iambic but on trochaic impulse, it is his translation where the contrast between iamb and Knittelvers is particularly strong.

(11) Olen, ah, kõik läbi uurind: mõtte-, arsti-, ja õigusteadust ja ka Uut ja Vana Seadust kaua palehigis puurind.
$\mathrm{Xx}$ X x Xx Xx

$\mathrm{Xx} \mathrm{Xx}$ x XxXx

$\mathrm{X} x \mathrm{X} \times \mathrm{Xx} \mathrm{Xx}$

$\mathrm{Xx} \mathrm{XxXx} \mathrm{Xx}$

These lines are written in almost pure trochees, only one foot contains a vemmalvärss-like redundant syllable.

The pattern of Knittelvers is broader than the iambic tetrameter, that is, purely iambic lines can be in composition with passages which, as a whole, can be interpreted as Knittelvers. The proportion of such iambic verses varies in passages in Knittelvers by different translators. In Goethe's original, the incidence of iambic verses in the context of Knittelvers is $75 \%$. The closest to it is Sang, in whose text the proportion of iamb is $76 \%$, while even closer to the pure iamb is Jürgenstein, whose index here is $83 \%$. And the freest is Ants Oras, who has iambic lines in only $69 \%$ of the cases, consider Chart 1 . It means that it was Oras who made an effort to bring to the fore the specific features of Knittelvers, distinguishing it from the iambic context.

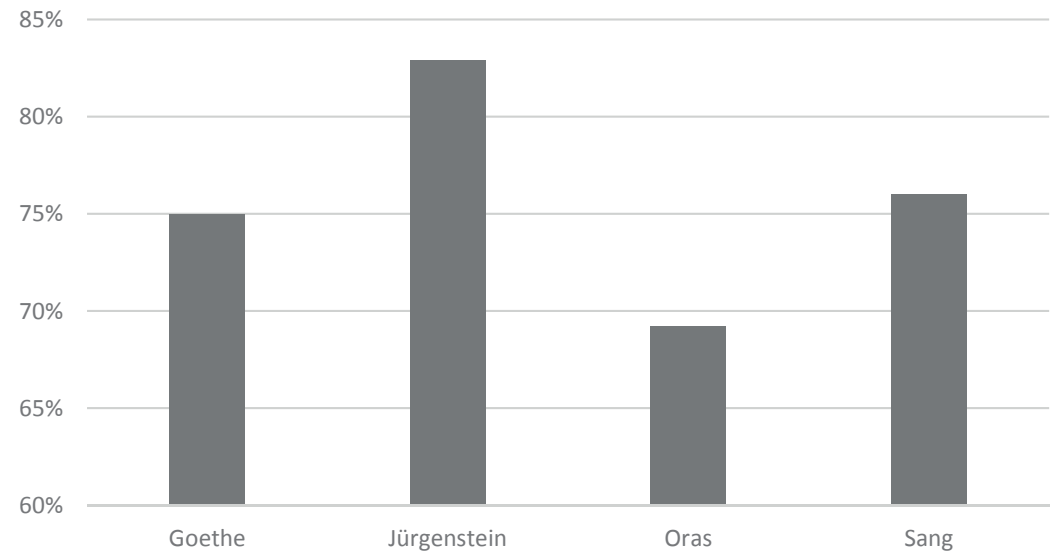

Chart 1. The proportion of iambic verses in passages written in Knittelvers in Faust.

It can be generally said that in his imitation of Knittelvers, Jürgenstein bends the iambic scheme yet mostly keeps the same system of versification; in Oras's translation, however, iamb and Knittelvers represent different systems of versification, respectively, syllabic-accentual and accentual. As concerns Sang, 
his changes are primarily in the metrical scheme. His Knittelvers is not based on iamb, but on trochee; even if trochaic verses are not statistically prevailing, his rhythm and style indicate the tradition of vemmalvärss. This solution is the closest to Goethe's idea of the contrast between literary and popular verse.

5. Let us focus now on just Oras's Knittelvers. Syllable count in lines varies from 8 to 12 syllables, which is very much similar to what we find in Goethe's original, where the variation between 7 and 12 syllables is observed (I have not found the statistics of Faust, Ernst Feise studies the Knittelvers of young Goethe; Feise 1908: 43). Just like in the original, eight-syllabic lines prevail, most of which are iambs with masculine endings, representing approximately $50 \%$ of the cases.

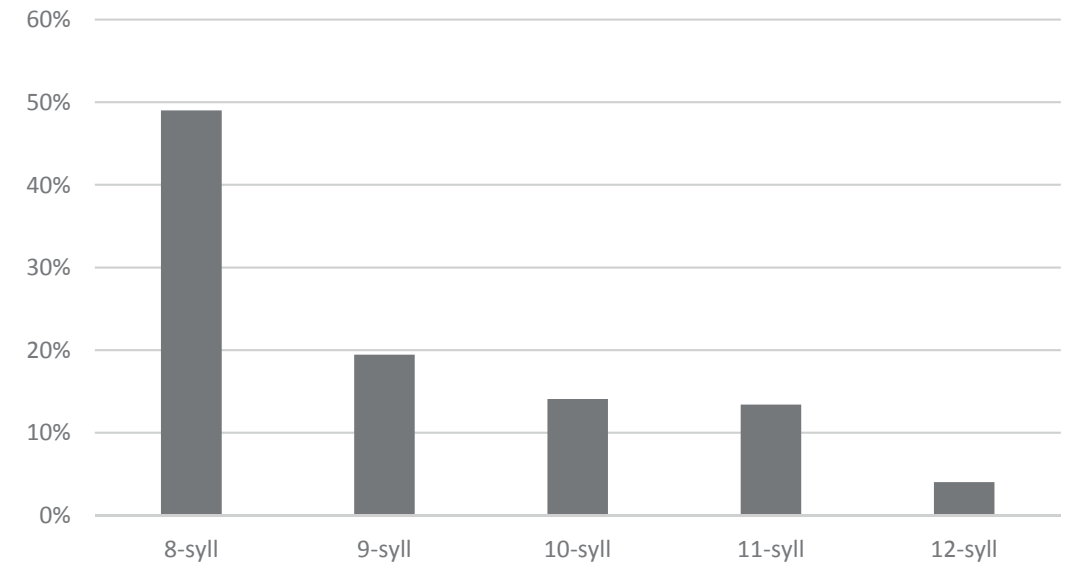

Chart 2. Syllabic composition of Oras's Knittelvers

In regards to anacrusis, he clearly prefers monosyllabic "iambic" anacruses, whereas verses without the anacrusis ("trochaic") and with disyllabic anacrusis ("anapaestic") are in minority (both ca $10 \%$ of the cases). 


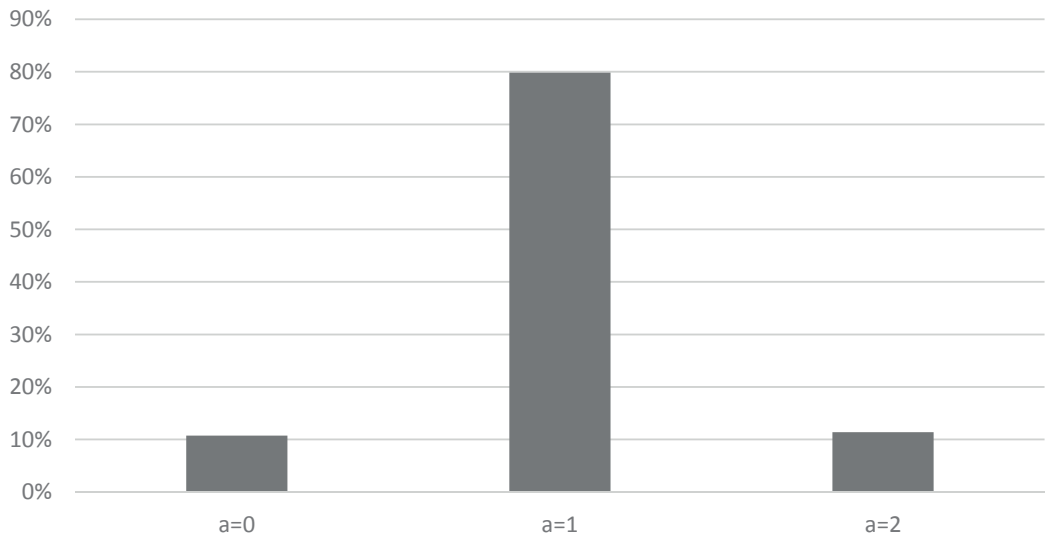

Chart 3. Anacruses in Oras's Knittelvers

Verses with masculine (catalectic) ending prevail (65\%), feminine (acatalectic) verses occur in $32 \%$ of the cases and only two verses $(0.1 \%)$ have dactylic (hypercatalectic) ending.

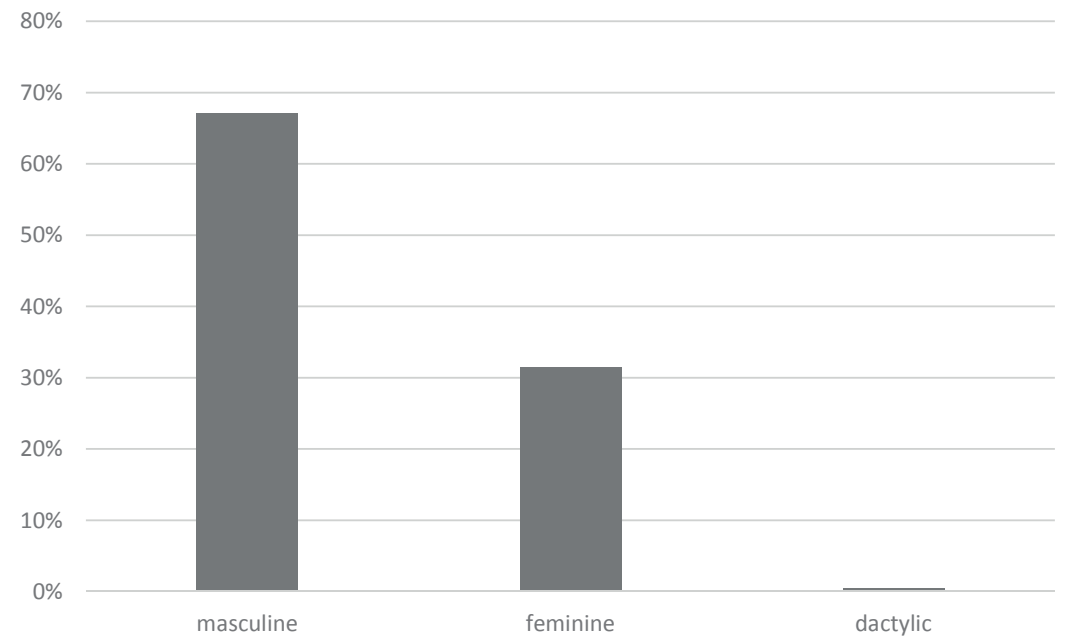

Chart 4. Line endings in Oras's Knittelvers

The most important parameter is connected with filling the interval between stresses, that is, positions $\mathrm{B}_{1}-\mathrm{B}_{3}$. There were only three verses in my material, which did not have four beats. The corresponding data are presented in Table 1. 


\begin{tabular}{|c|c|c|c|}
\hline & $\mathrm{B}_{1}$ & $\mathrm{~B}_{2}$ & $\mathrm{~B}_{3}$ \\
\hline 1-syll & $77.4 \%$ & $69.9 \%$ & $84.9 \%$ \\
\hline 2-syll & $21.9 \%$ & $30.1 \%$ & $15.1 \%$ \\
\hline 3-syll & $0.7 \%$ & $0.0 \%$ & $0.0 \%$ \\
\hline
\end{tabular}

Table 1. Syllable count in positions $B_{1}-B_{3}$

Only one verse contains a trisyllabic interval, and it occurs in position $B_{1}$ :

ninapidi õppureid, õnnetuid hingi ( $\mathrm{Xxxx} \mathrm{Xxx} \mathrm{Xxx} \mathrm{Xx})$

Monosyllabic intervals prevail which, together with a monosyllabic anacrusis, create the iambic inertia, while the proportion of such intervals in higher in positions $B_{1}$ and $B_{3}$. (For the distribution of rhythmic forms in Oras's Knittelvers see Appendix 1.)

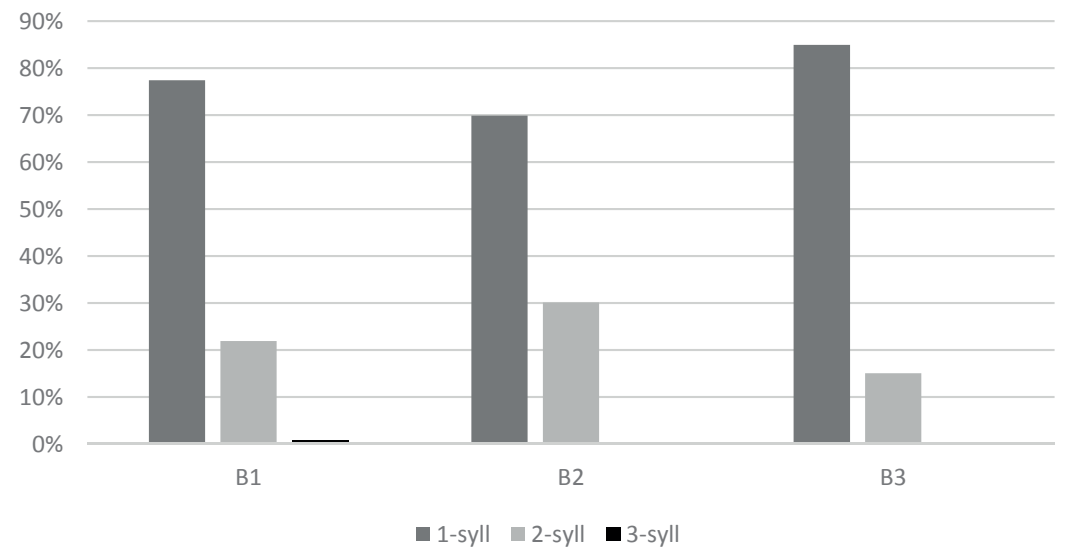

Chart 5. Number of syllables in positions $B_{1}, B_{2}$ and $B_{3}$.

6. Faust also contains other meters which depart from the syllabic-accentual monotony, like, for instance, Freie Rhythmen. Here we will treat only one of these, the so-called adoneus or adonic verse.

The ancient adoneus was almost exclusively used as the final part of the Sapphic stanza, yet in the medieval poetry it was also used in a stichic form (Norberg 2004: 72-74), usually in hymns. This was the very tradition Goethe continued with his Choir of Angels in Faust. The metrical scheme of the ancient and medieval Latin adoneus is the following:

(MS2) ABBAB 
There are simple correspondence rules:

$\left(\mathrm{CR}_{\mathrm{a}} 1\right)$ One and only one syllable corresponds to each position A and $\mathrm{B}$.

$\left(\mathrm{CR}_{2}\right.$ 2) A heavy syllable corresponds to position A.

(CR 3 ) A light syllable corresponds to position $B$.

$\left(\mathrm{CR}_{\mathrm{a}} 4\right)$ A syllable with optional quantity corresponds to position $\mathrm{B}_{3}$.

Both in the case of Sapphic and stichic adoneus we are dealing with a syllabic-quantitative verse with a very stable structure:

$-\cup \cup-\mathrm{X}$

The transition from the quantitative principle to the accentual principle was, at first, limited to the reformulation of CR2 and CR3:

$\left(\mathrm{CR}_{\mathrm{a}} 5\right)$ A stressed syllable corresponds to position A.

$\left(\mathrm{CR}_{\mathrm{a}}\right.$ 6) An unstressed syllable corresponds to position $\mathrm{B}$.

As a result, the following form evolved:

$\mathrm{XxxXx}$

Differently from the quantitative adoneus, the stressed version of adoneus is highly variable and ambivalent. Mono- and disyllabic words at the beginning of verse created an opportunity to interpret these both as dactylic and iambic ${ }^{5}$ :

$\mathrm{XxxXx} \rightarrow \mathrm{xXxXx}$

For example, lines such as tormavaid pü̈̈deid can be interpreted only as dactylic, verses such as et sa ei lange or et meeleheitu can be either dactylic or iambic, while it would be more natural to interpret the lines such as miks taevaid taotad? as iambic. Nevertheless, all these cases were primarily interpreted as dactylic. The reason is that, in the Estonian dactyl and triple meters in general, it is possible to fill the interval between stresses with a disyllabic word carrying a strong stress, while its adjacent position can be filled with a monosyllabic word carrying a weak stress.

The following developments were specific to accentual and syllabic-accentual verse. First, in these systems of versification, especially when dealing with the rhymed verse, often a variation of line endings occurs. Thus, on the one hand, verses with masculine ending evolved, while on the other hand there are verses with dactylic endings:

$\mathrm{XxxXx} \rightarrow \mathrm{XxxX}$

$\mathrm{XxxXx} \rightarrow \mathrm{XxxXxx}$

5 Such rhythmical moves were known already in medieval rhythmic adonic verses (Norberg 2004: 91). 
Consider, for example, Goethe's Choir of Angels, where the feminine endings vary with the dactylic ones (endings of the same type are rhymed with one another).

(12) Christ ist erstanden!

Freude dem Sterblichen,

Den die verderblichen,

Schleichenden, erblichen

Mängel unwanden.

Next, in verses with "iambic" anacrusis an additional syllable was introduced to the interval between stresses, allowing these to better fit into the context of triple meters.

$\mathrm{XxxXx} \rightarrow \mathrm{xXxXx} \rightarrow \mathrm{xXxxXx}$

The last transformation was related to the circumstance that dactylic ending, in turn, can end with a monosyllabic word, which sometimes carries the main stress, consider the last three verses (especially the penultimate one) of the following passage from Faust:

(12) Hat der Begrabene

Schon sich nach oben,

Lebend Erhabene,

Herrlich erhoben;

Ist er in Werdeluft

Schaffender Freude nah:

Ach! an der Erde Brust

Sind wir zum Leide da.

$\mathrm{XxxXx} \rightarrow \mathrm{XxxXxx} \rightarrow \mathrm{XxxXxX}$

As a result of all these transformations, the interval between stresses started to vary in the range of 1 to 2 syllables, the anacrusis varied from 0 to 2 syllables and the ending between 0 and 2 syllables. Thus, among the verses with two stresses, verses with three stresses occurred:

$(\mathrm{x})(\mathrm{x}) \mathrm{Xx}(\mathrm{x}) \mathrm{X}(\mathrm{x})(\mathrm{x})$ and $(\mathrm{x}) \mathrm{Xx}(\mathrm{x}) \mathrm{X}(\mathrm{x})(\mathrm{X})$. 
All the possible variants are actually present, but in Oras's translation of Faust adonic verses and disyllabic trochees are distinguished, that is, lines like $\mathrm{XxXx}$ and $\mathrm{XxX}$ occur, but not in adonic context. For this reason such lines were not included in the current statistics. (For the distribution of rhythmic forms in Oras's adoneus see Appendix 2.)

The syllabic structure of the adoneus in Oras is demonstrated on the following Chart.

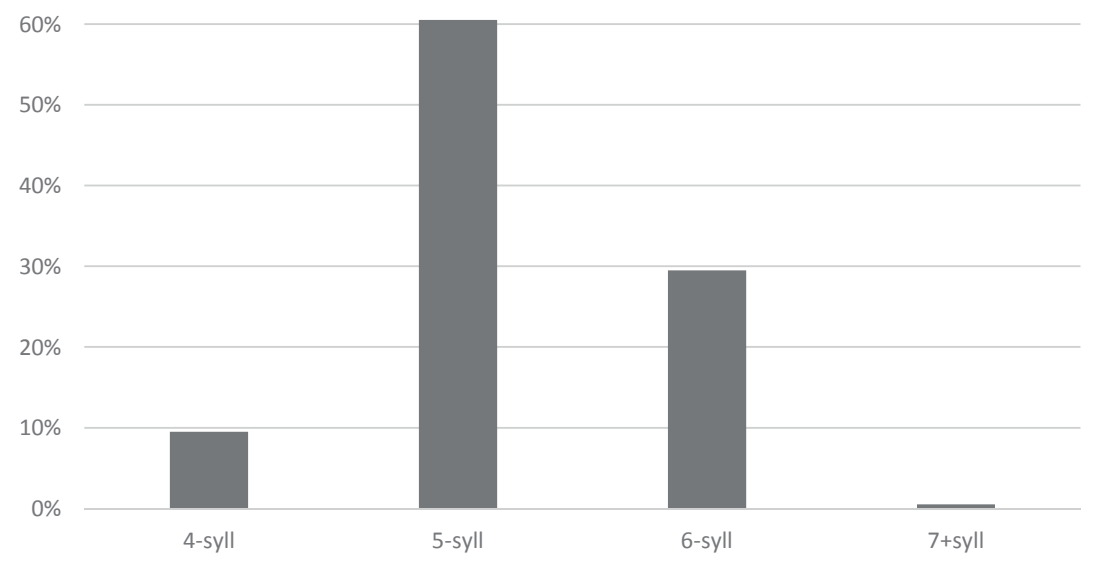

Chart 6. The syllabic structure of Oras's adoneus

Lines with five syllables are absolutely prevailing, which is in accordance with the structure of adoneus. Yet there is also a substantial amount of lines with six syllables.

The distribution of different rhythmic structures is showed in Chart 7 (it has to be kept in mind, that all these names - iambs, dactyls, and so on, are purely conditional, these are not verse meters, but homonymic rhythmic forms). 


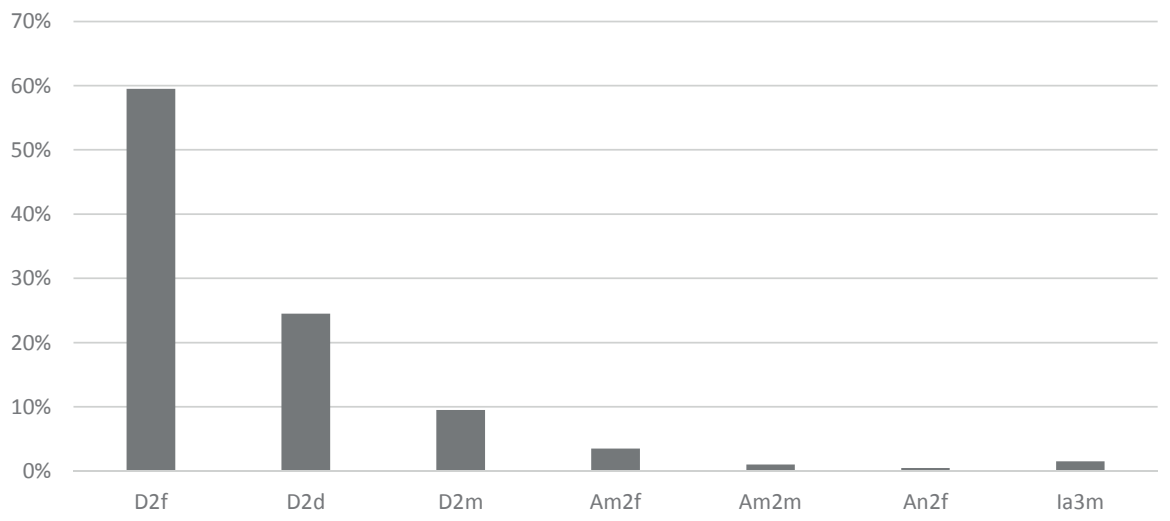

Chart 7. The distribution of different rhythmic structures in Oras's adoneus ( $D$ - dactyl, Am - amphibrachiac, An - anapaest, la - iamb; f, $m$ and $d$ - respectively, feminine, masculine and dactylic endings).

Finally, adoneus in general and, in particular, Oras's adoneus is an ambivalent form, which allows the interpretation of most verse lines in two and sometimes even in three different ways. Such ambivalent verses make up more than half of the analysed sample $(54,8 \%)$.

7. Knittelvers and adoneus are two verse meters with completely different origins and stylistic qualities. The first is associated with the German tradition and has a vulgar connotation, the second is related with the Antiquity and the Middle Ages and has mostly literary connotations. Nevertheless, already Goethe used adoneus both for the Choir of Angels and the soldiers' song, maintaining their hymnic intonations. Differently from German poetry, in Estonia, Knittelvers and adoneus did not become independent verse meters: Oras's experiments described above did not find imitators. Yet what connects these verse meters, is not their non syllabic-accentual versification. Already Klopstock claimed that the nature of classical forms is close to old German "polymetrical" poetry (altdeutsche Polymetrie). When Goethe wrote his Faust, the usage of non-syllabic accentual meters was not rare in high literary forms. In Estonian poetry the situation was different and thus, in order to fight German-like syllabic-accentual monotony, Oras turned to both French syllabic verse and ancient quantitative verse. However, and paradoxically in a way, he found models for diversification of verse also from German poetry itself, that is, from Goethe's Faust. 


\section{References}

Arndt, Erwin 1968. Deutsche Verslehre. Berlin: Volk und Wissen Volkseigener Verlag.

Altmann, Vivien; Altmann, Gabriel 2005. Erlkönig und Mathematik. In: Quantitative Linguistics 61. http://ubt.opus.hbz-nrw.de/volltexte/2005/325/pdf/Erlkoenig0.pdf (accessed December 10, 2015)

Bailey, James 1969. The stress-meter of Goethe's Der Erlkönig. In: Language and style 2(4): 339-351.

Chisholm, David 1975. Goethe's Knittelvers: a prosodic analysis. Bonn: Bouvier.

Feise, Ernst 1908. Der Knittelvers des jungen Goethe. Leipzig: Roth und Schunke.

Goethe, Johann Wolfgang 1920. Faust. J.W. Goethe kurbmäng. Eestistanud A[nton]. Jürgenstein. Tartu: Postimees.

Goethe, Johann Wolfgang 1955. Faust: tragöödia esimene osa. Tõlkinud Ants Oras. Lund: Eesti Kirjanike Kooperatiiv.

Goethe, Johann Wolfgang 1962. Faust: tragöödia teine osa. Tõlkinud Ants Oras. [Lund]: Eesti Kirjanike Kooperatiiv.

Goethe, Johann Wolfgang 1972. Faust. Tõlkinud August Sang. Tallinn: Eesti Raamat.

Heusler, Andreas 1929. Deutsche Versgeschichte mit Einschluss des altenglischen und altnordischen Stabreimverses. Bd. III. Berlin und Leipzig: Walter de Gruyter Co.

Kazartsev, Evgeny 2011. Zur Rhythmik der frühen niederländischen und deutschen Jamben. In: Küper, Christoph (ed.), Current Trends in Metrical Analysis. (Littera: Studies in Language and Literature 2). Bern, etc.: Peter Lang, 251-263.

Lotman, Maria-Kristiina; Lotman, Mihhail 2013. The quantitative structure of Estonian syllabic-accentual trochaic tetrameter. In: Trames: Journal of the Humanities and Social Sciences 17(67/62): 243-272.

Lotman, Maria-Kristiina; Lotman, Mihhail 2014. The Accentual Structure of Estonian Syllabic-Accentual Iambic Tetrameter. In: Studia Metrica et Poetica 1.2: 71-102.

Lotman, Mihhail 2011. Verse structure and its cognitive model (hexameter and septenary). In: Küper, Christoph (ed.), Current Trends in Metrical Analysis. (Littera: Studies in Language and Literature 2). Bern, etc.: Peter Lang, 307-328.

Norberg, Dag 2004. An introduction to the study of medieval Latin versification. Washington, D. C.: Catholic University of America Press.

Opitz, Martin 1624. Buch von der Deutschen Poeterey. Breslau: Müller. 
Peep, Harald 1969. Eesti lü̈rika kujunemislugu aastail 1917-1929. Tartu [Unpublished dissertation].

Põldmäe, Jaak 1978. Eesti värsiõpetus. Tallinn: Eesti Raamat.

Tarlinskaja, Marina 1992. Metrical Typology: English, German, and Russian Dolnik Verse. In: Comparative Literature 44(1): 1-21.

Tarlinskaja, Marina 1993. Strict Stress-Meter in English Poetry: Compared with German and Russian. Calgary: University of Calgary Press.

Webster, Thomas B. L. 1970. The Greek Chorus. London: Methuen. 
Appendix 1. The distribution of rhythmical forms in

Knittelvers (Goethe's Faust in Oras's translation)

\begin{tabular}{|c|c|c|c|}
\hline 1 & Ning siin ma, rumal, vilets vend & $\mathrm{xXxXxXxX}$ & $48.32 \%$ \\
\hline 2 & Ei ilge vadada täis vaeva & $\mathrm{xXxXxXxXx}$ & $14.77 \%$ \\
\hline $2 \mathrm{a}$. & Olen nüüd, ah, filosoofiat & $\mathrm{XxXxXxXx}$ & $0.67 \%$ \\
\hline 4 & Pean rusikaid kokku pigistama & $\mathrm{xXxxXxXxXx}$ & $0.67 \%$ \\
\hline 5 & Kui ma ei eksi, näen kahte meest & 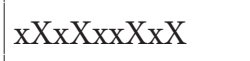 & $3.36 \%$ \\
\hline $5 a$. & Härra Urianile aukoht ant & 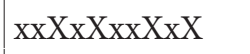 & $0.67 \%$ \\
\hline 6 & Ja lehviks luhal su pehmes looris & $\mathrm{xXxXxxXxXx}$ & $4.03 \%$ \\
\hline 8 & Lööks pihuks-puruks sellise sohi & $\mathrm{xXxXxXxxXx}$ & $1.34 \%$ \\
\hline 9 & Veel pole siin olnud mu olek pikk & 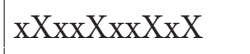 & $2.68 \%$ \\
\hline $9 a$. & Kuis juba kümmekond aastaid vean & 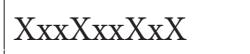 & $0.67 \%$ \\
\hline $9 b$. & Nõiad Brocheni poole viib öine õhk & 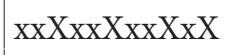 & $4.03 \%$ \\
\hline $10 a$. & Pole ka usku, et inimsoole & $\mathrm{XxxXxxXxXx}$ & $0.67 \%$ \\
\hline $10 \mathrm{~b}$. & Üsna hädaga sain ema käe alt lahti & 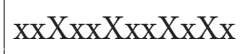 & $2.68 \%$ \\
\hline 11a. & Andkem ausale au ja väärsele palk! & 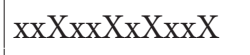 & $0.67 \%$ \\
\hline 12 & Kas on teil ju mõnd siin vaadata jõutud? & $\mathrm{xXxxXxXxxXx}$ & $0.67 \%$ \\
\hline $12 \mathrm{a}$. & See siin su maailm, see olla maailm! & $\mathrm{XxxXxXxxXx}$ & $0.67 \%$ \\
\hline 13 & Näen sama targalt kui ennegi end & 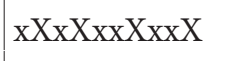 & $0.67 \%$ \\
\hline $13 a$. & Peame lugu emisest - emast ja seast & 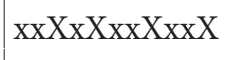 & $1.34 \%$ \\
\hline 14 & Ma palun, aidake teie mind nõutut! & $\mathrm{xXxXxxXxxXx}$ & $0.67 \%$ \\
\hline 15 & See tunne mul põletab südame seest & 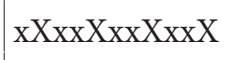 & $2.01 \%$ \\
\hline $15 \mathrm{a}$. & Koeralgi oleks see elu liig hull! & 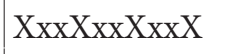 & $2.01 \%$ \\
\hline 16 & Magistrid, professorid, doktorid, papid & 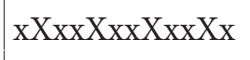 & $0.67 \%$ \\
\hline $16 a$. & Kibedal õhinal õppind ja puurind & $\mathrm{XxxXxxXxxXx}$ & $3.36 \%$ \\
\hline $16 \mathrm{~b}$. & Ninapidi õppureid, õnnetuid hingi & XxxxXxxXxxXx & $0.67 \%$ \\
\hline
\end{tabular}

Table shows only verses actually present in the sample. 
Appendix 2. The distribution of rhythmical forms in adoneus (Goethe's Faust in Oras's translation)

\begin{tabular}{|l|ll|c|}
\hline 1 & Kõik, kes meil jalus & $\mathrm{XxxXx}$ & $59.5 \%$ \\
$1 \mathrm{a}$ & Kõik, mis neis ribades & $\mathrm{XxxXxx}$ & $24.5 \%$ \\
$1 \mathrm{~b}$ & Varjavas maas & $\mathrm{XxxX}$ & $9.5 \%$ \\
2 & Me mõõka ja oda & $\mathrm{xXxxXx}$ & $3.5 \%$ \\
$2 \mathrm{a}$ & Ja kütkete all & $\mathrm{xXxxX}$ & $1.0 \%$ \\
3 & Mis meil riitadeks laotud & $\mathrm{xxXxxXx}$ & $0.5 \%$ \\
4 & Õiged me rütm ja viis? & $\mathrm{XxxXxX}$ & $0.5 \%$ \\
5 & Kas on kõik paarid reas & $\mathrm{xXxXxX}$ & $1.0 \%$ \\
\hline
\end{tabular}

Table shows only verses actually present in the sample. 